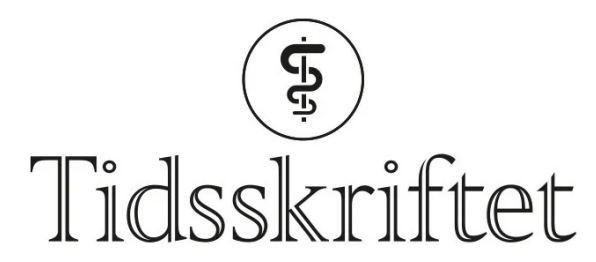

DEN NORSKE LEGEFORENING

\title{
Rusrelaterte forgiftninger ved Legevakten i Oslo i 2014-18
}

ORIGINALARTIKKEL

\section{JENNY VICTORIA TRAN}

Medisinsk fakultet

Universitetet i Oslo

Hun har bidratt med idé, studiedesign, datainnsamling, dataanalyse, utforming av manus og godkjenning av innsendte manusversjon.

Jenny Victoria Tran er medisinstudent.

Forfatteren har fylt ut ICMJE-skjemaet og oppgir ingen interessekonflikter.

\section{METTE BREKKE}

Allmennmedisinsk forskningsenhet Universitetet i Oslo Hun har bidratt med studiedesign, revisjon av manus og godkjenning av innsendte manusversjon. Mette Brekke er professor.

Forfatteren har fylt ut ICMJE-skjemaet og oppgir ingen interessekonflikter.

\section{ODD MARTIN VALLERSNES}

o.m.vallersnes@medisin.uio.no Avdeling for allmennmedisin Universitetet i Oslo og Legevakten i Oslo

Han har bidratt med idé, studiedesign, datainnsamling, hjelp til dataanalyse, revisjon av manus og godkjenning av innsendte manusversjon.

Odd Martin Vallersnes er førsteamanuensis og legeskiftleder.

Forfatteren har fylt ut ICMJE-skjemaet og oppgir ingen interessekonflikter.

\section{BAKGRUNN}

Rusrelatert forgiftning er potensielt farlig og et tegn på risikabel rusatferd. For å være rustet til å håndtere pasienter med rusrelatert forgiftning trenger vi oppdatert kunnskap om hvilke rusmidler vi kan forvente å møte. De fleste rusrelaterte forgiftninger i Oslo behandles ved legevakten, og vi beskriver forgiftningene der i perioden 2014-18.

\section{MATERIALE OG METODE}

Vi inkluderte alle pasienter behandlet for rusrelatert forgiftning ved Legevakten i Oslo i 2014-18, unntatt rene alkoholforgiftninger. For 2018 inkluderte vi også disse. Pasientene ble funnet retrospektivt ved gjennomgang av innskrivingslistene i legevaktens journalsystem. Rusmiddeldiagnostikken var basert på behandlende leges kliniske vurdering. 


\section{RESULTATER}

I perioden 2014-18 ble 8116 tilfeller av rusrelatert forgiftning behandlet ved Legevakten $\mathrm{i}$ Oslo, om vi ser bort fra rene alkoholforgiftninger. De hyppigst forekommende rusmidlene var heroin (3 237 tilfeller), benzodiazepiner (2 196), amfetamin/metamfetamin (1 827), cannabis (1 081), gammahydroksybutyrat (GHB) (904), kokain (569) og uspesifiserte opioider (546). Trenden i antall tilfeller per år var stigende for sentralstimulerende midler, cannabis og GHB, og synkende for benzodiazepiner. Antallet heroinforgiftninger sank fram til 2017, men steg igjen i 2018. I 2018 var det 4021 rusrelaterte forgiftninger, hvorav 2022 var rene etanolforgiftninger.

\section{FORTOLKNING}

Antallet forgiftninger $\emptyset \mathrm{kte}$ for de fleste rusmidlene i 2014-18, men sank for heroin og benzodiazepiner.

\section{HOVEDFUNN}

Insidensen av rusrelatert forgiftning ved Legevakten i Oslo var stabil fra 2014 til 2017, med en forbigående nedgang i 2016, fulgt av en økning i 2018.

I 2018 behandlet Legevakten i Oslo 4021 rusrelaterte forgiftninger, hvorav 2022 var rene etanolforgiftninger.

Fra 2014 til $2018 ø$ kte insidensen for de fleste rusmidlene, men falt for heroin og benzodiazepiner.

Forekomsten av uspesifiserte, trolig mer langtidsvirkende, opioider økte i 2017 og 2018.

Rusrelatert forgiftning er farlig i seg selv og er en markør for risikabel rusatferd. I

kohortstudier fra Oslo er det funnet en 5-10 ganger høyere dødelighet enn forventet 5-20 år etter rusrelatert forgiftning, og opptil 30 ganger høyere enn forventet etter opioidforgiftning (1-3).

Panoramaet av rusmidler som opptrer ved forgiftning varierer over tid og fra sted til sted (4-6). I nyere tid har vi sett en epidemi av opioidoverdoser og -dødsfall, særlig i USA (므), og $\emptyset$ kende bruk av potente fentanylderivater (5,7.). Videre har det dukket opp et utall nye rusmidler, gjerne omtalt som nye psykoaktive stoffer (NPS), der mer enn 6oo ulike typer er rapportert i Europa det siste tiåret $(5, \underline{8})$.

For tiden er det i Norge årlig 250-30o narkotikaoverdosedødsfall og 350-400 alkoholrelaterte dødsfall $(9, \underline{10})$. Etanol er uten sammenligning det mest utbredte rusmidlet i Norge og stod for drøyt halvparten av rusrelaterte forgiftninger behandlet ved Legevakten i Oslo i $2012(\underline{11}, \underline{12})$. Cannabis, heroin, amfetamin, kokain og benzodiazepiner har vært i bruk i Norge siden 1960- og 1970-årene (10). Metylendioksymetamfetamin (MDMA) dukket opp i 198o-årene, og gammahydroksybutyrat (GHB) i 199o-årene (10 ). Nye psykoaktive stoffer forekommer nå også her. Parametoksymetamfetamin (PMMA) tok flere liv i Norge i et utbrudd i 2010-11 (13), og nye psykoaktive stoffer ble påvist i 8 \% av rusrelaterte forgiftninger i Oslo i 2014 (14).

Overvåking av trender innen rusrelaterte forgiftninger gir kunnskap om hva vi kan forvente å møte og gjør oss dermed bedre rustet til å håndtere pasientene. Oppdaterte studier trengs stadig, og overvåking av rusrelaterte forgiftninger i Oslo er et bidrag til oversikten over det europeiske bildet. I Oslo behandles de fleste rusrelaterte forgiftninger ved legevakten, og forekomst er tidligere kartlagt i studier, senest i 2008 og $2012(15,16)$.

Vi beskriver trender over tid i rusrelaterte forgiftninger behandlet ved Legevakten i Oslo fra 2014 til 2018, og ser på inntatte rusmidler, enkle forløpsdata og pasientenes kjønn og alder.

\section{Materiale og metode}


Studien var observasjonell med retrospektiv dataregistrering fra pasientjournaler ved Allmennlegevakten ved Legevakten i Oslo for perioden 1.1.2014 til 31.12.2018. Studien var basert på inklusjonskriteriene og variabelsettet utviklet av forskningsnettverket the European Drug Emergencies Network (Euro-DEN) $(\underline{4}, \mathbf{1 7}$.).

SETTING

Legevakten i Oslo, i Storgata 40, er døgnåpen og har om lag 200 ooo konsultasjoner per år, fordelt på allmennlegevakt og skadelegevakt. Allmennlegevakten behandler de fleste

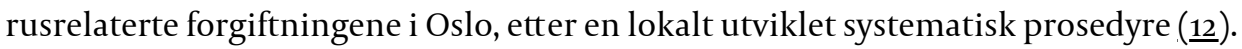

INKLUSJON

Pasientene ble funnet ved gjennomgang av innskrivingslistene i Allmennlegevaktens elektroniske journalsystem. Vi inkluderte alle pasienter behandlet for rusrelatert forgiftning, definert som toksisk virkning av en psykoaktiv substans pasienten hadde benyttet for å ruse seg. Pasienter ble ikke inkludert om rusmidlet var tatt i suicidal hensikt eller var ufrivillig påført. I henhold til Euro-DENs inklusjonskriterier, som vi brukte uendret de første fire årene, ble heller ikke pasienter med ren alkoholforgiftning inkludert. For bedre sammenligning med tidligere lokale studier, der etanolforgiftninger utgjorde halvparten av rusmiddelforgiftningene $(\underline{15}, \underline{16})$, utvidet vi inklusjonskriteriene fra og med 2018 til også å omfatte rusrelaterte etanolforgiftninger.

Inklusjon og dataregistrering ble gjort sekvensielt av sisteforfatter og medisinstudenter under sisteforfatters veiledning.

DATAREGISTRERING

Vi registrerte pasientens kjønn og alder, inntatte rusmidler, tid for innkomst, observasjonstid ved legevakten og videre tiltak. Rusmiddeldiagnostikken var basert på behandlende leges journalførte vurdering, som igjen var basert på opplysninger fra pasienten, pårørende, ambulanse og/eller politi, samt kliniske symptomer og tegn. Det ble ikke gjort toksikologisk laboratoriediagnostikk. Amfetamin og metamfetamin ble kategorisert sammen.

STATISTIKK

For å beskrive trender i forekomsten av de ulike rusmidlene beregnet vi insidenser per 1 ooo innbyggere per år, basert på antall forgiftninger ved Legevakten i Oslo og antall innbyggere i Oslo kommune med alder $\geq 12$ år (묘).

Analysene ble utført i IBM SPSS versjon 25. Vi beskrev kategoriske variabler med antall og prosentandeler og kontinuerlige variabler med medianer og interkvartilområder.

ETIKK

Studien ble gjort som et kvalitetssikringsprosjekt og ble vurdert av Personvernombudet ved Oslo universitetssykehus som ikke framleggingspliktig for Regional komité for medisinsk og helsefaglig forskningsetikk.

\section{Resultater}

Totalt ble 8116 tilfeller av rusrelatert forgiftning behandlet ved Legevakten i Oslo i perioden 2014-18, om vi ser bort fra rene alkoholforgiftninger. Median alder var 34 år (interkvartilområde 27-43, aldersspenn 13-85), 6236 (77\%) var menn. De hyppigst forekommende rusmidlene var heroin med 3237 (40\%) tilfeller, benzodiazepiner med 2196 (27\%) og amfetamin/metamfetamin med 1827 (23\%)(tabell 1).

\section{Tabell 1}


Rusmidler inntatt ved rusrelaterte forgiftninger behandlet ved Legevakten i Oslo 2014-18. Rusmiddeldiagnostikken var basert på behandlende leges kliniske vurdering. Noen pasienter hadde inntatt flere rusmidler. Resultater er angitt som antall (n) (\%).

\begin{tabular}{|c|c|c|c|c|c|c|}
\hline & $\begin{array}{l}2014 \\
(n=1 \\
576)\end{array}$ & $\begin{array}{l}2015 \\
(n=1 \\
605)\end{array}$ & $\begin{array}{l}2016 \\
(n=1 \\
327)\end{array}$ & $\begin{array}{l}2017 \\
(n=1 \\
609)\end{array}$ & $\begin{array}{l}2018 \\
(n=1 \\
999)\end{array}$ & $\begin{array}{l}\text { Totalt } \\
(n=8116)\end{array}$ \\
\hline Heroin & $\begin{array}{r}715 \\
(45)\end{array}$ & $\begin{array}{r}703 \\
(44)\end{array}$ & $\begin{array}{l}620 \\
(47)\end{array}$ & $\begin{array}{r}527 \\
(33)\end{array}$ & $\begin{array}{r}672 \\
(34)\end{array}$ & $3237(40)$ \\
\hline Benzodiazepiner & $\begin{array}{l}496 \\
(31)\end{array}$ & $\begin{array}{l}495 \\
(31)\end{array}$ & $\begin{array}{l}387 \\
(29)\end{array}$ & $\begin{array}{l}397 \\
(25)\end{array}$ & $421(21)$ & $2196(27)$ \\
\hline Amfetamin/metamfetamin & $\begin{array}{r}313 \\
(20)\end{array}$ & $\begin{array}{l}368 \\
(23)\end{array}$ & $\begin{array}{r}312 \\
(24)\end{array}$ & $\begin{array}{l}394 \\
(24)\end{array}$ & $\begin{array}{l}440 \\
(22)\end{array}$ & $1827(23)$ \\
\hline Cannabis & $181(12)$ & $\begin{array}{l}225 \\
(14)\end{array}$ & $\begin{array}{l}165 \\
(12)\end{array}$ & $\begin{array}{l}228 \\
(14)\end{array}$ & $\begin{array}{l}282 \\
(14)\end{array}$ & $1081(13)$ \\
\hline Gammahydroksybutyrat (GHB) & $\begin{array}{r}152 \\
(10)\end{array}$ & 169 (11) & $\begin{array}{r}140 \\
(11)\end{array}$ & $\begin{array}{r}200 \\
(12)\end{array}$ & $\begin{array}{l}243 \\
(12)\end{array}$ & $904(11)$ \\
\hline Kokain & $99(6)$ & $111(7)$ & $74(6)$ & $103(6)$ & $182(9)$ & $569(7)$ \\
\hline $\begin{array}{l}\text { Metylendioksymetamfetamin } \\
\text { (MDMA) }\end{array}$ & $38(2)$ & $47(3)$ & $62(5)$ & $68(4)$ & $76(4)$ & $291(4)$ \\
\hline Metadon & $42(3)$ & $52(3)$ & $48(4)$ & $71(4)$ & $44(2)$ & $257(3)$ \\
\hline Buprenorfin & $40(3)$ & $24(1)$ & $17(1)$ & $22(1)$ & $18(1)$ & $121(1)$ \\
\hline Lysergsyredietylamid (LSD) & $16(1)$ & $18(1)$ & $18(1)$ & $16(1)$ & $47(2)$ & $115(1)$ \\
\hline Z-hypnotika & $16(1)$ & $16(1)$ & $15(1)$ & $13(1)$ & $\begin{array}{l}8(< \\
0,5)\end{array}$ & $68(1)$ \\
\hline Andre/uspesifiserte opioider ${ }^{1}$ & $110(7)$ & $126(8)$ & $40(3)$ & $169(11)$ & $\begin{array}{l}268 \\
(13)\end{array}$ & $713(9)$ \\
\hline Annet & $58(4)$ & $53(3)$ & $71(5)$ & $80(5)$ & $63(3)$ & $325(4)$ \\
\hline Ukjent & $38(2)$ & $40(2)$ & $62(5)$ & $192(12)$ & $145(7)$ & 477 (6) \\
\hline Etanol $^{2}$ & $\begin{array}{r}418 \\
(27)\end{array}$ & $\begin{array}{l}455 \\
(28)\end{array}$ & $\begin{array}{r}351 \\
(26)\end{array}$ & $\begin{array}{l}428 \\
(27)\end{array}$ & $\begin{array}{r}573 \\
(29)\end{array}$ & 2225 (27) \\
\hline
\end{tabular}

${ }^{1}$ Uspesifiserte opioider utgjorde totalt 546 (77\% av andre/uspesifiserte opioider), hhv. 69, 93, 15, 135 og 234 for årene 2014-18

${ }^{2}$ Etanol tatt i tillegg til andre rusmidler. Omfatter ikke rene alkoholforgiftninger

\section{TRENDER}

Insidensen av rusrelatert forgiftning var 2,48 per 1 ooo innbyggere i 2014 og holdt seg deretter jevn, med en nedgang til 2,02 i 2016 og en økning til 2,97 i 2018 (figur 1). Nedgangen i 2016 omfattet alle rusmidler unntatt MDMA. 


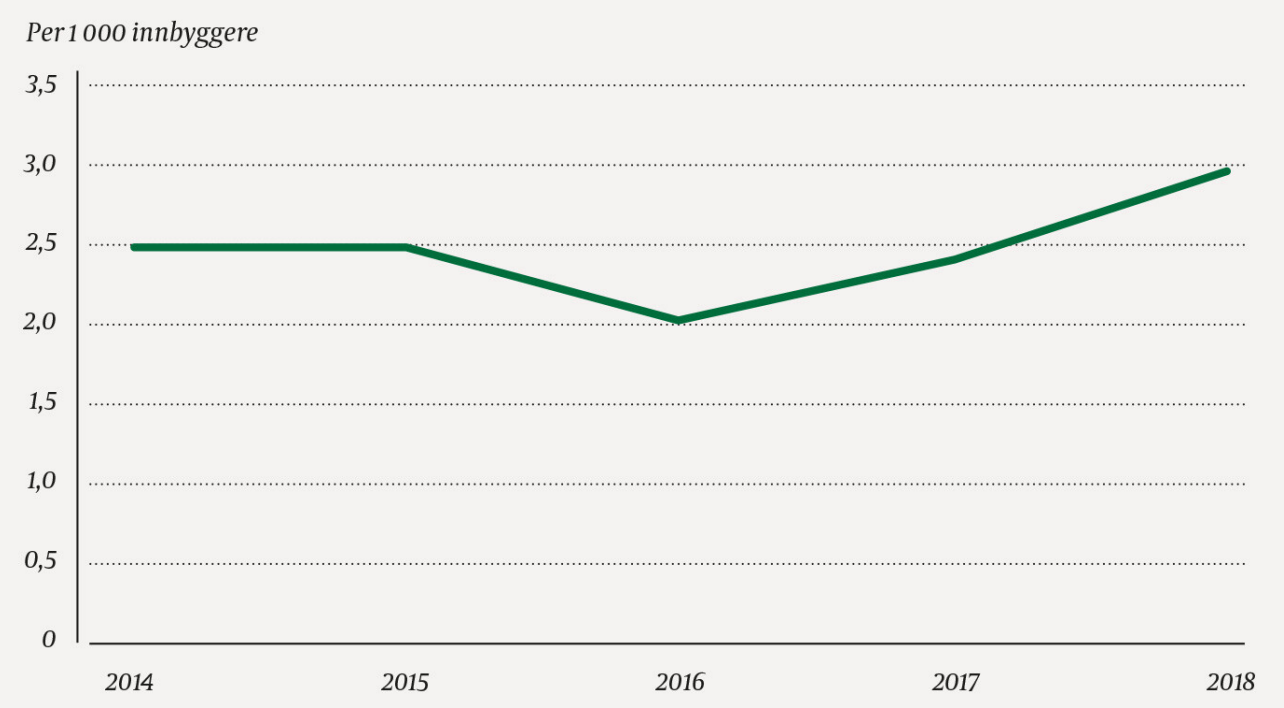

Figur 1 Estimert insidens av rusrelaterte forgiftninger behandlet ved Legevakten i Oslo 2014-18 (omfatter ikke rene etanolforgiftninger).

Fra 2014 til 2018 falt insidensen av forgiftninger med heroin fra 1,13 per 1 ooo innbyggere til 1,oo, ledsaget av en $\varnothing \mathrm{kning}$ av andre/uspesifiserte opioider fra o,17 til o,40 (tabell 2). Insidensen $\varnothing \mathrm{kte}$ for sentralstimulerende rusmidler: amfetamin/metamfetamin fra o,49 til 0,65, kokain fra 0,16 til o,27 og MDMA fra o,o6 til o,11. Insidensen økte også for cannabis (fra 0,29 til o,42) og GHB (fra o,24 til o,36), mens den sank for benzodiazepiner (fra o,78 til o,63).

\section{Tabell 2}

Antall rusrelaterte forgiftninger behandlet ved Legevakten i Oslo 2014-18 per 1 ooo innbyggere per år. Rusmiddeldiagnostikken var basert på behandlende leges kliniske vurdering. Noen pasienter hadde inntatt flere rusmidler.

\begin{tabular}{|c|c|c|c|c|c|}
\hline & $2014^{1}$ & $2015^{1}$ & $2016^{1}$ & $2017^{1}$ & $2018^{1}$ \\
\hline Heroin & 1,13 & 1,09 & 0,94 & 0,79 & 1,00 \\
\hline Amfetamin/metamfetamin & 0,49 & 0,57 & 0,47 & 0,59 & 0,65 \\
\hline Benzodiazepiner & 0,78 & 0,76 & 0,59 & 0,60 & 0,63 \\
\hline Cannabis & 0,29 & 0,35 & 0,25 & 0,34 & 0,42 \\
\hline Andre/uspesifiserte opioider ${ }^{2}$ & 0,17 & 0,19 & 0,06 & 0,25 & 0,40 \\
\hline Gammahydroksybutyrat (GHB) & 0,24 & 0,26 & 0,21 & 0,30 & 0,36 \\
\hline Kokain & 0,16 & 0,17 & 0,11 & 0,15 & 0,27 \\
\hline Metylendioksymetamfetamin (MDMA) & 0,06 & 0,07 & 0,09 & 0,10 & 0,11 \\
\hline Metadon & 0,07 & 0,08 & 0,07 & 0,11 & 0,07 \\
\hline Lysergsyredietylamid (LSD) & 0,03 & 0,03 & 0,03 & 0,02 & 0,07 \\
\hline Buprenorfin & 0,06 & 0,04 & 0,03 & 0,03 & 0,03 \\
\hline
\end{tabular}

${ }^{1}$ De estimerte insidensene er basert på antall innbyggere i Oslo kommune med alder $\geq 12$ år; 2014: 634 463; 2015: 647 676; 2016: 658 390; 2017: 666 759; 2018: 673 469 (18)

${ }^{2}$ Uspesifiserte opioider utgjorde 77 \% av tilfellene av andre/uspesifiserte opioider 
Kjønnsfordelingen holdt seg uendret gjennom perioden, med rundt 77 \% menn, og median alder var stabil rundt 34 år (tabell 3 ). Andelen pasienter som ble brakt med ambulanse, $ø$ kte fra $56 \%$ til $66 \%$. Samtidig sank andelen som ble innlagt i somatisk sykehus fra $18 \%$ til $11 \%$. Ingen døde på legevakten.

\section{Tabell 3}

Demografi og forløp for pasienter behandlet for rusrelatert forgiftning ved Legevakten i Oslo 2014-18. Rene etanolforgiftninger er ikke inkludert. Resultater er angitt som n (\%).

\begin{tabular}{|c|c|c|c|c|c|c|}
\hline & 2014 & 2015 & 2016 & 2017 & 2018 & Totalt \\
\hline \multicolumn{7}{|l|}{ Kjønn } \\
\hline Menn & $1234(78)$ & $\begin{array}{r}1236 \\
(77)\end{array}$ & $1014(76)$ & $\begin{array}{r}1214 \\
(75)\end{array}$ & $\begin{array}{r}1538 \\
(77)\end{array}$ & $\begin{array}{r}6236 \\
(77)\end{array}$ \\
\hline Kvinner & $342(22)$ & $369(23)$ & $313(24)$ & $\begin{array}{l}395 \\
(25)\end{array}$ & $461(23)$ & $\begin{array}{r}1880 \\
(23)\end{array}$ \\
\hline $\begin{array}{l}\text { Alder, median } \\
\text { (interkvartilområde) }^{1}\end{array}$ & $34(26-45)$ & $\begin{array}{r}34(27- \\
44)\end{array}$ & $\begin{array}{r}34(26- \\
43)\end{array}$ & $\begin{array}{r}33(27- \\
42)\end{array}$ & $\begin{array}{r}35(27- \\
44)\end{array}$ & $\begin{array}{r}34(27- \\
43)\end{array}$ \\
\hline Brakt av ambulanse & $887(56)$ & $922(57)$ & $801(60)$ & $\begin{array}{l}992 \\
(62)\end{array}$ & $\begin{array}{l}1323 \\
(66)\end{array}$ & $\begin{array}{r}4925 \\
(61)\end{array}$ \\
\hline $\begin{array}{l}\text { Observasjonstid, median } \\
\text { (interkvartilområde) }\end{array}$ & $\begin{array}{r}3: 57 \\
(1: 55-5: 51)\end{array}$ & $\begin{array}{r}3: 31 \\
(1: 44- \\
5: 27)\end{array}$ & $\begin{array}{r}3: 41 \\
(1: 46- \\
5: 43)\end{array}$ & $\begin{array}{c}4: 02 \\
(1: 59- \\
6: 01)\end{array}$ & $\begin{array}{r}3: 45 \\
(1: 49- \\
5: 46)\end{array}$ & $\begin{array}{r}3: 47 \\
(1: 50- \\
5: 46)\end{array}$ \\
\hline \multicolumn{7}{|l|}{ Videre tiltak $^{2}$} \\
\hline Innlagt somatisk sykehus & $287(18)$ & $285(18)$ & 247 (19) & $257(16)$ & $211(11)$ & $\begin{array}{r}1287 \\
(16)\end{array}$ \\
\hline $\begin{array}{l}\text { Innlagt psykiatrisk } \\
\text { sykehus }\end{array}$ & $63(4)$ & $65(4)$ & $58(4)$ & $39(2)$ & $98(5)$ & $323(4)$ \\
\hline $\begin{array}{l}\text { Ferdigbehandlet ved } \\
\text { legevakt }\end{array}$ & $937(59)$ & $\begin{array}{r}1026 \\
(64)\end{array}$ & 779 (59) & $\begin{array}{r}1047 \\
(65)\end{array}$ & $\begin{array}{l}1391 \\
(70)\end{array}$ & $\begin{array}{r}5180 \\
(64)\end{array}$ \\
\hline $\begin{array}{l}\text { Forlot legevakt under } \\
\text { behandling }\end{array}$ & $288(18)$ & $229(14)$ & $243(18)$ & $266(17)$ & $298(15)$ & $\begin{array}{r}1324 \\
(16)\end{array}$ \\
\hline Totalt & $1576(100)$ & $\begin{array}{l}1605 \\
(100)\end{array}$ & $\begin{array}{r}1327 \\
(100)\end{array}$ & $\begin{array}{l}1609 \\
(100)\end{array}$ & $\begin{array}{l}1999 \\
(100)\end{array}$ & $\begin{array}{r}8116 \\
(100)\end{array}$ \\
\hline
\end{tabular}

${ }^{1}$ Data mangler for 162 tilfeller

${ }^{2}$ Data mangler for to tilfeller

\section{ETANOL I 2018}

I 2018 var det 2022 rene etanolforgiftninger. Median alder var 38 år (interkvartilområde 2453, aldersspenn 13-85), 1329 (66\%) var menn. Median observasjonstid ved legevakten var $3 \mathrm{t}$ 32 min (interkvartilområde 1 t 56 min - 5 t 10 min), deretter ble 73 (4\%) innlagt i somatisk sykehus, 10 (o,5\%) i psykiatrisk sykehus, 1592 (79\%) ferdigbehandlet ved legevakten, og 347 (17\%) forlot legevakten under behandling. Ingen døde på legevakten.

Medregnet forgiftningene der etanol var tatt i tillegg til andre rusmidler, var det totalt 2595 etanolforgiftninger i 2018, en insidens på 3,85 per 1000 innbyggere. 
Totalt var det 4021 rusrelaterte forgiftninger i 2018, en insidens på 5,97 per 1000 innbyggere.

\section{Diskusjon}

Ser vi bort fra rene alkoholforgiftninger, var den totale insidensen av rusrelatert forgiftning ved Legevakten i Oslo stabil fra 2014 til 2017, med en forbigående nedgang i 2016, for deretter å øke til 2,97 per 1 ooo innbyggere i 2018. Gjennom femårsperioden var insidensen $\emptyset$ kende for de fleste rusmidlene, men fallende for heroin og benzodiazepiner. Flere pasienter ble brakt med ambulanse, mens færre ble innlagt i somatisk sykehus. Medregnet rene etanolforgiftninger ble 4021 pasienter behandlet for rusrelatert forgiftning ved Legevakten i Oslo i 2018, en insidens på 5,97 per 1 ooo innbyggere.

TRENDER

Sammenlignet med tidligere studier har antallet rusrelaterte forgiftninger ved Legevakten i Oslo økt voldsomt, fra 1714 i 2008 via 2328 i 2012 til 4021 i 2018 (15, 16). Beregnet på samme måte som i vår studie var insidensen 3,o6 per 1 ooo innbyggere i 2008 og 3,80 i 2012 (innbyggere i Oslo kommune med alder $\geq 12$ år: 560484 i 2008; 613285 i 2012 (ㅁ)), mot 5,97 i 2018.

Tallmessig var økningen størst for etanol, fra 1236 i 2008 via 1684 i 2012 til 2595 i 2018 (15, 16). Det samlede alkoholforbruket i Norge har vært stabilt siden 2012, mens alkoholbruken blant ungdom er synkende (1ㅡ). Når antallet etanolforgiftninger likevel øker, er en mulig forklaring at de som drikker mye, drikker mer, et mønster som har vært sett både i Sverige og i Storbritannia $(\underline{19}, \underline{20})$. En annen mulighet er at alkoholforbruket kan ha flyttet seg hjemmefra til utelivet, noe som øker muligheten for å befinne seg i det offentlige rom når alkoholforgiftningen inntreffer.

Blant opioidene var det en tydelig nedgang i insidensen av heroinforgiftninger. En mulig forklaring er at flere heroinoverdoser finner sted på sprøyterommet (kommunalt lokale for

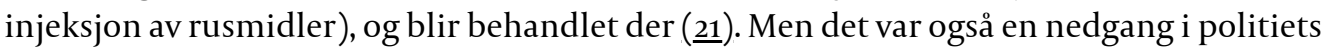
heroinbeslag gjennom femårsperioden, som kan tyde på at det har blitt mindre heroin i

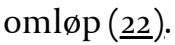

Mot slutten av perioden $\emptyset \mathrm{kte}$ insidensen av forgiftninger med uspesifiserte opioider. Legene ved Allmennlegevakten journalfører ofte uspesifisert opioid som forgiftningsagens når spesifikke opplysninger ikke foreligger og pasienten fortsatt framstår klinisk opioidpåvirket når ruseffekten av heroin burde være over. Dette kan tyde på at langtidsvirkende opioider opptrer oftere enn tidligere, noe som tydelig er utviklingen ved overdosedødsfall (9.). Økningen i uspesifiserte opioider kan skjule en økning i forgiftninger med metadon og buprenorfin, som i vårt materiale var henholdsvis stabile og synkende. I en studie fra 2014 med toksikologisk prøvetaking påviste vi metadon hos mange pasienter der dette ikke var klinisk mistenkt (14).).

Illegale fentanylderivater og/eller langtidsvirkende formuleringer av opioidanalgetika er også mulige agens. Forgiftninger med disse er økende i andre europeiske land og i USA (5, 7.) og økte i norske politibeslag i 2017 og 2018 (르). Forskrivningen av oksykodonpreparater i Norge $\varnothing$ kte med $27 \%$ fra 2014 til 2018 (23). Økende forekomst av forgiftninger med langtidsvirkende opioider gir grunn til bekymring, særlig sett på bakgrunn av den amerikanske opioidoverdoseepidemien (ㅁ$)$.

$\emptyset$ kningen i antall forgiftninger med sentralstimulerende rusmidler fra 2014 til 2018 er en trend som har pågått siden $2008(\underline{15}, \underline{16})$. Antallet GHB-forgiftninger $\emptyset \mathrm{kte}$ med $150 \%$ fra 2008 til $2012(\underline{16})$, men var så stabilt fram til en ny økning i 2017 og 2018. Dette gjenspeiler kurven for politibeslag (르). 
Insidensen av cannabisforgiftninger var $\emptyset$ kende. Denne tendensen er tydelig helt fra 2008 $(\underline{15}, \underline{16})$. Siden 2012 har bruken og beslagstallene vært stabile, men cannabisen har blitt sterkere $(9, \underline{22})$. I de fleste tilfellene var cannabis sannsynligvis, som $f ø r$, tatt i tillegg til det

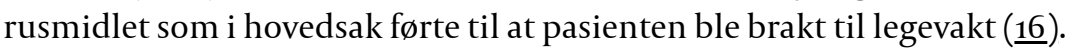

At flere pasienter ble brakt med ambulanse og færre sendt videre til sykehus fra legevakt, kan tyde på at en del av legevaktpasientene har mindre alvorlige forgiftninger enn før. En mulig forklaring er at publikum har lavere terskel for å tilkalle ambulanse. En annen mulighet er at flere ruser seg i det offentlige rom og derfor blir påtruffet ved overdose.

\section{STYRKER OG BEGRENSNINGER}

Datainnsamlingen var retrospektiv og inklusjonen avhengig av at pasienten var innskrevet med en problemstilling som ga mistanke om rusrelatert forgiftning. Det er dermed sannsynlig at en del tilfeller ikke ble inkludert.

Hovedtyngden av rusrelaterte forgiftninger i Oslo blir behandlet ved legevakten. Imidlertid blir de alvorligste tilfellene brakt direkte til sykehus av ambulansetjenesten, anslagsvis 300 per år, og en del pasienter blir igjen på stedet etter behandling av ambulanse, blant

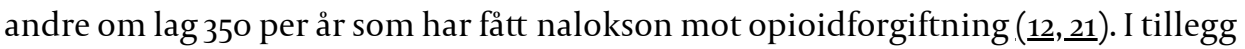
kommer om lag 100 årlige overdosedødsfall $(9, \underline{10})$ og et ukjent antall personer som overlever sin forgiftning uten kontakt med helsevesenet. Våre tall gir således ikke et fullstendig bilde av byens rusrelaterte forgiftninger, men gir en god pekepinn for Osloområdet.

Insidensene vi har beregnet, er ikke eksakte mål for forekomstene av rusrelaterte forgiftninger blant Oslos innbyggere, men egnede mål for trender over tid. Selv om en tredjedel av legevaktpasientene med rusrelatert forgiftning i 2012 var utenbysfra (24), valgte vi å bruke Oslos befolkning som grunnlag for insidensberegningene. For å få en representativ risikopopulasjon satte vi nedre aldersgrense på 12 år, ettersom rusrelatert forgiftning er svært sjelden blant personer yngre enn dette.

Rusmiddeldiagnostikken var ikke basert på toksikologiske analyser, men på den behandlende legens kliniske vurdering. Dette gjør agensdiagnostikken unøyaktig. Imidlertid finner man i studier som sammenligner klinisk vurdering med laboratoriediagnostikk, at pasientene stort sett har inntatt de rusmidlene det er klinisk mistanke om, i tillegg til noen flere (14).

Selv om sisteforfatter lærte opp og veiledet de datainnsamlende medisinstudentene, kan det være systematiske ulikheter i praktiseringen av inklusjonskriterier og agensklassifisering. Dette kan være forklaringen på insidensfallet i 2016. Politibeslagene var verken spesielt store eller små dette året (22). Imidlertid økte insidensen av MDMA, mens insidensen av heroin falt ytterligere året etter, noe som kan tale for at 2016-funnene er reelle.

Vi kategoriserte amfetamin og metamfetamin sammen, da det kliniske bildet er likt og brukerne i Oslo sjelden skiller mellom dem. I studieperioden stod metamfetamin for en

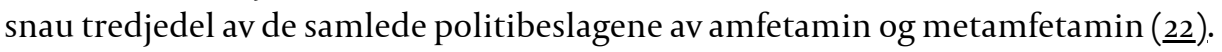

\section{KONKLUSJON}

Insidensen av rusrelatert forgiftning ved Legevakten i Oslo var stabil fra 2014 til 2017, med en forbigående nedgang i 2016 og økning i 2018. I perioden 2014-18 økte insidensen for de fleste rusmidlene, med unntak av heroin og benzodiazepiner. De siste par årene var det en $\emptyset$ kning for uspesifiserte opioider. Dette er bekymringsfullt, siden de uspesifiserte opioidene kan representere mer potente og/eller langtidsvirkende opioider. 


\section{LITTERATUR}

1. Bjornaas MA, Jacobsen D, Haldorsen T et al. Mortality and causes of death after hospital-treated selfpoisoning in Oslo: a 20-year follow-up. Clin Toxicol (Phila) 2009; 47: 116-23. [PubMed][CrossRef]

2. Bjornaas MA, Bekken AS, Ojlert A et al. A 20-year prospective study of mortality and causes of death among hospitalized opioid addicts in Oslo. BMC Psychiatry 2008; 8: 8. [PubMed][CrossRef]

3. Lund C, Bjornaas MA, Sandvik L et al. Five-year mortality after acute poisoning treated in ambulances, an emergency outpatient clinic and hospitals in Oslo. Scand J Trauma Resusc Emerg Med 2013; 21: 65. [PubMed][CrossRef]

4. Dines AM, Wood DM, Yates $C$ et al. Acute recreational drug and new psychoactive substance toxicity in Europe: 12 months data collection from the European Drug Emergencies Network (EuroDEN). Clin Toxicol (Phila) 2015; 53: 893-900. [PubMed][CrossRef]

5. European drug report 2019: trends and developments. Lisbon, Portugal: European monitoring centre for drugs and drug addiction (EMCDDA), 2019. https://www.emcdda.europa.eu/edr2019_en Lest 4.4.2020.

6. Kolodny A, Courtwright DT, Hwang CS et al. The prescription opioid and heroin crisis: a public health approach to an epidemic of addiction. Annu Rev Public Health 2015; 36: 559-74. [PubMed] [CrossRef]

7. Wilson N, Kariisa M, Seth P et al. Drug and opioid-involved overdose deaths: United States, 20172018. MMWR Morb Mortal Wkly Rep 2020; 69: 290-7. [PubMed][CrossRef]

8. Krabseth HM, Tuv SS, Strand MC et al. Nye psykoaktive stoffer. Tidsskr Nor Legeforen 2016; 136: 7147. [PubMed][CrossRef]

9. Folkehelseinstituttet. Narkotika i Norge. https://www.fhi.no/nettpub/narkotikainorge/ Lest 4.4.2020.

10. Skretting A, Bye EK, Vedøy TF et al. Rusmidler i Norge 2016. Oslo: Folkehelseinstituttet; 2016. https://www.fhi.no/publ/2017/rusmidler-i-norge-2016/ Lest 4.4.2020.

11. Folkehelseinstituttet. Alkohol i Norge. https://www.fhi.no/nettpub/alkoholinorge/ Lest 4.4.2020.

12. Vallersnes OM, Jacobsen D, Ekeberg $\emptyset$ et al. Outpatient treatment of acute poisoning by substances of abuse: a prospective observational cohort study. Scand J Trauma Resusc Emerg Med 2016; 24: 76. [PubMed][CrossRef]

13. Vevelstad M, Øiestad EL, Middelkoop G et al. The PMMA epidemic in Norway: comparison of fatal and non-fatal intoxications. Forensic Sci Int 2012; 219: 151-7. [PubMed][CrossRef]

14. Vallersnes OM, Persett PS, Øiestad EL et al. Underestimated impact of novel psychoactive substances: laboratory confirmation of recreational drug toxicity in Oslo, Norway. Clin Toxicol (Phila) 2017; 55: 636-44. [PubMed][CrossRef]

15. Lund C, Vallersnes OM, Jacobsen D et al. Outpatient treatment of acute poisonings in Oslo: poisoning pattern, factors associated with hospitalization, and mortality. Scand J Trauma Resusc Emerg Med 2012; 20: 1. [PubMed][CrossRef]

16. Vallersnes OM, Jacobsen D, Ekeberg $\emptyset$ et al. Patients presenting with acute poisoning to an outpatient emergency clinic: a one-year observational study in Oslo, Norway. BMC Emerg Med 2015; 15: 18. [PubMed][CrossRef]

17. Wood DM, Heyerdahl F, Yates CB et al. The European Drug Emergencies Network (Euro-DEN). Clin Toxicol (Phila) 2014; 52: 239-41. [PubMed][CrossRef]

18. Oslo kommune. Statistikkbanken. https://statistikkbanken.oslo.kommune.no Lest 1.7.2019.

19. Hallgren M, Leifman H, Andréasson S. Drinking less but greater harm: could polarized drinking habits explain the divergence between alcohol consumption and harms among youth? Alcohol Alcohol 2012; 47: 581-90. [PubMed][CrossRef]

20. Holmes J, Ally AK, Meier PS et al. The collectivity of British alcohol consumption trends across different temporal processes: a quantile age-period-cohort analysis. Addiction 2019; 114: 1970-80. [PubMed][CrossRef]

21. Madah-Amiri D, Skulberg AK, Braarud AC et al. Ambulance-attended opioid overdoses: An examination into overdose locations and the role of a safe injection facility. Subst Abus 2019; 40:3838. [PubMed][CrossRef] 
22. Narkotika- og dopingstatistikk 2019. Oslo: KRIPOS, 2019. https://www.politiet.no/globalassets/o4aktuelt-tall-og-fakta/narkotika/narkotika-og-dopingstatistikk-kripos-2019.pdf Lest 4.4.2020.

23. Folkehelseinstituttet. Reseptregisteret. http://www.reseptregisteret.no Lest 24.4.2020.

24. Akopian M, Vallersnes OM, Jacobsen D et al. Levekår i Oslos bydeler og legevaktbehandlet rusmiddelforgiftning. Tidsskr Nor Legeforen 2015; 135: 1943-8. [PubMed][CrossRef]

Publisert: 29. april 2021. Tidsskr Nor Legeforen. DOI: 10.4045/tidsskr.20.0751

Mottatt 19.8.2020, første revisjon innsendt 5.1.2021, godkjent 12.2.2021.

Publisert under åpen tilgang CC BY-ND. Lastet ned fra tidsskriftet.no 26. april 2023. 